\title{
Evaluation of MolecuTech Real MTB-ID for MTB/NTM Detection Using Direct Specimens
}

\author{
Hye-young Wang ${ }^{1 * *}$, Hyunwoo Jin ${ }^{2, *}$, Hyeeun Bang', Yeon-Im Choi ${ }^{2}$, Eun-mi Park', \\ Won-jung Koh ${ }^{4}$, Hyeyoung Lee ${ }^{2}$ \\ ${ }^{1} M \& D$, Inc. ${ }^{2}$ Department of Biomedical Laboratory Science, College of Health Sciences, Yonsei University, Wonju, \\ ${ }^{3} Y D$ Diagnostics, Yongin, ${ }^{4}$ Division of Pulmonary and Critical Care Medicine, Department of Medicine, \\ Samsung Medical Center, Sungkyunkwan University School of Medicine, Seoul, Korea
}

Background: The differentiation of Mycobacterium tuberculosis (MTB) from nontuberculous mycobacteria (NTM) is of primary importance for infection control and choice of antimicrobial therapy. The diagnosis of diseases caused by NTM is difficult because NTM are prevalent in the environment and have fastidious properties. In this study, we evaluated the real-time PCR-based MTB/NTM detection kit for its usefulness in discrimination of MTB and NTM species.

Methods: A total of 155 sputum specimens whose AFB staining smear and culture were positive were used for this study. Among them, 59 and 96 samples had been identified as MTB and NTM, respectively. DNA obtained from sputum specimens was subjected to analysis with MolecuTech Real MTB-ID ${ }^{\mathbb{R}}$ (M\&D, Korea) real-time PCR-based MTB/NTM detection kit.
Subsequently, the results of MolecuTech Real MTB$I^{R}$ were compared with AFB staining smear and culture results.

Results: The positive rate of MolecuTech Real MTB$I^{\circledR}$ to detect MTB and NTM was $98.3 \%(58 / 59)$ and 97.9 (94/96), respectively, using sputum specimens. Conclusion: For detection of MTB/NTM, the sensitivity and specificity of MolecuTech Real MTB-ID ${ }^{\mathbb{R}}$ were comparable to those of conventional methods. Therefore, this study suggests the usefulness of real-time PCR-based MolecuTech Real MTB-ID ${ }^{\mathbb{R}}$ for rapid detection of MTB/NTM from direct specimens. (Korean J Clin Microbiol 2011;14:103-109)

Key Words: Mycobacterium tuberculosis, Non-tuberculous mycobacteria, Real-time PCR

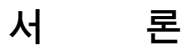

현재 전 세계 인구의 약 $1 / 3$ 정도가 결핵균(Mycobacterium tuberculosis, MTB)에 감염되어 있으며, 매년 약 3 백만 명의 인 구가 결핵으로 인해 사망하고 또 다른 약 8 백만 명의 새로운 환자가 발생하는 것으로 추정되고 있다[1]. 이러한 결핵의 가장 확실한 진단 방법은 $\mathrm{MTB}$ 에 의한 감염을 증명하는 것으로 임 상검체에서 MTB을 검출하는 것이다[2,3]. 결핵균뿐만 아니라 비결핵항산균(nontuberculous mycobacteria, NTM) 역시 결핵을 유발할 수 있다. 실제로 NTM 빈도가 높은 지역에서는 항산균 도말 양성 객담의 $30 \%$ 에서 $50 \%$ 정도에서 $\mathrm{NTM}$ 이 분리되고 있으며[4] 우리나라의 경우 기존 $10.3 \%$ 에서 $12.2 \%$ 까지 보고되 던 것이 최근에는 $30 \%$ 수준까지 항상균 도말 양성 객담에서의 NTM 분리 비율이 증가하고 있는 추세이다[5]. 더군다나 NTM

Received 3 March, 2011, Revised 23 June, 2011

Accepted 22 July, 2011

Correspondence: Hyeyoung Lee, Department of Biomedical Laboratory Science, College of Health Sciences, Yonsei University, 234 Maejiri, Heungup-myeon, Wonju 220-710, Korea. (Tel) 82-33-760-2740, (Fax) 82-33-760-2561, (E-mail) hyelee@yonsei.ac.kr

*These authors are equally contributed.
은 균종에 따라 자연적으로 가지고 있는 항결핵 약제내성이 다 르기 때문에 항결핵 치료에 저항성을 나타낼 수 있으므로 $\mathrm{MTB}$ 와 NTM을 신속하게 구별할 수 있는 적절한 검사방법이 요구되고 있다[6].

결핵의 진단에는 보편적으로 항산균 도말검사와 배양검사를 이용해왔다. 항산균 도말검사는 신속하고 비용이 적게 소모되 며 기법이 간편하다는 장점이 있으나 민감도는 $22 \%$ 내지는 $78 \%$ 로 비교적 낮고 $\mathrm{MTB}$ 와 NTM을 구분할 수 없다는 단점이 있다. 결핵진단의 표준법인 배양검사는 민감도는 $80 \%$ 에서 $85 \%$ 로 항산성 염색법보다 높게 보고되고 있고, 특이도가 $100 \%$ 에 가까워 확진법으로 널리 사용되고 있지만 시간이 오래 걸린다는 단점이 있다[7,8]. 또한, 균 배양시간을 단축하기 위해 액체배지를 이용한 자동배양기기에 의한 방법이 일부 사용되 고 있으나 이 역시 2주 이상의 배양기간이 소요되며 비용이 많 이 들고 검사과정이 복잡하고, MTB와 NTM을 구별하기 위해 서는 추가의 동정과정이 필요하다는 단점이 있다[7,8].

최근에는 분자진단 기술이 발달되면서 이를 이용한 결핵 진 단법들이 많이 개발되어, 신속하면서도 민감도와 특이도가 높 은 분자생물학적 방법을 이용하여 환자로부터 분리한 검체에 
서 직접 MTB를 검출하는 방법의 이용이 점차 늘어나고 있는 추세이다[9-17]. 그러나 분자진단에 많이 사용되는 검사법인 polymerase chain reaction (PCR), hybridization assay 등은 증폭 산물을 확인하기 위해서 전기영동을 하는 과정이나 교합반응 을 수행하는 과정에서 검사환경을 오염시킬 수 있다[8,18]. 따 라서 최근에는 전기영동의 과정이 필요 없고 비교적 짧은 시간 내에 검사결과를 확인할 수 있는 실시간-중합효소연쇄반응 (real-time PCR)을 기반으로 한 다양한 키트들이 개발되어 상용 화되고 있다.

Real-time PCR을 기본으로 한 MTB 검출 키트로는 Enhanced Mycobacterium tuberculosis Direct Test (E-MTD, GeneProbe, San Diego, CA, USA)와 Amplicor Mycobacterium tuberculosis Test (Amplicor, Roche Diagnostic Systems, Inc., Branch-burg, NJ, USA) 등이 수입되어 상용화되고 있다[19,20]. 국내제품으로 AdvanSure TB/NTM real-time PCR kit (LG생명 과학, Korea), MolecuTech Real-MTB ID (M\&D, Korea) 등이 상품화되어 있는데 두 제품 모두 MTB와 NTM을 동시에 검출 할 수 있다는 장점이 있다. AdvanSure TB/NTM real-time PCR kit는 MTB complex에만 존재한다고 알려진 IS6110 유전자 부 위를 target으로 하고 있다. MolecuTech Real-MTB ID는 최근 IS6110 유전자가 결여된 MTB가 존재한다는 보고가 증가함에 따라[21,22] MTB에만 존재하는 것으로 밝혀진 RD (region of difference) 유전자 부위[23]를 추가함으로써 IS6110을 가지고 있지 않은 MTB에 의한 위음성 결과를 방지하고 MTB 검출을 위해 두 개의 유전자를 증폭함으로써 민감도를 최대로 높이고 자 한 점에서 AdvanSure TB/NTM real-time PCR kit와 차이가 있다.

따라서 본 연구에서는 결핵환자의 객담 검체를 대상으로 하 여 MolecuTech Real-MTB ID를 수행하여 MTB 및 NTM의 감 별검출을 시도하고 동일한 검체로부터 배양된 결핵균을 대상 으로 하여 기존의 분자유전학적 방법으로 확인한 검사결과와 비교하여 MolecuTech Real-MTB ID의 민감도와 특이도를 평 가해 보았다.

\section{대상 및 방법}

\section{1. 호흡기 검체 및 검체의 처리}

2009년 3월부터 4월까지 삼성서울병원에서 항산균 도말검사 와 배양검사가 동시에 의뢰된 검체 중 항산성 염색결과 trace 이상으로 판독된 기관지 세척액 13예, 객담 142예 총 155 임상 검체를 대상으로 하였다. 호흡기 검체는 검체와 동량의 $4 \%$ $\mathrm{NaOH}$ 를 넣고 잘 혼합한 다음 30 분간 실온 방치 후 $3,000 \mathrm{rpm}$ 에서 30 분간 원심분리 한 뒤 상층액을 제거하였다. 여기에 DNA extraction solution $100 \mu \mathrm{L}$ 를 넣고, 1 분간 vortex하고, $100^{\circ} \mathrm{C}$ 에서 10 분간 가열한 후, 실온에서 $13,000 \mathrm{rpm}$ 으로 3 분간
원심분리하여 얻은 상층액을 MolecuTech Real-MTB ID 검사 에 사용하였다.

\section{2. 항산균 도말 및 배양}

결핵균 검출을 위한 항산균 도말 검사와 배양검사는 삼성서 울병원에서 수행되었다. 호흡기 검체의 항산균 도말검사는 Carbol-fuchsin을 이용한 Ziehl-Neelsen 염색법을 이용하였고 그 결과는 미국 질병예방통제국의 기준에 따라 판독하였다. 배 양검사는 BACTEC MGIT 960 (Becton Dickinson Microbiology System, Sparks, Md, USA)와 3\% Ogawa 배지(Shin-yang chemical, Seoul, Korea)를 이용하여 수행하였으며 결핵균을 최대 8 주까지 배양하였다. 또한, $\mathrm{MTB}$ 와 $\mathrm{NTM}$ 의 검출민감도를 비교 분석하기 위해서 표준결핵균주 $\mathrm{MTB} \mathrm{H} 37 \mathrm{Rv}$ 와 $M$. intracellulare의 균체를 Ogawa 배지에 3주간 배양하였다.

\section{3. 항산균의 DNA 분리 및 동정}

직접 검체를 $\mathrm{BACTEC} \mathrm{MGIT} 960$ system에 접종하고 $37^{\circ} \mathrm{C}$ 에서 배양한 후, 배양액의 일부를 취하여 $100^{\circ} \mathrm{C}$ 에서 20 분간 가 열하고 $13,000 \mathrm{rpm}$ 에서 5 분간 원심분리한 후 상층액을 취하는 방법으로 핵산을 분리하였다. 분리된 핵산은 REBA Myco-ID (M\&D, Wonju, Korea)를 이용하여 제조사가 제공하는 실험설 명서에 따라 NTM 균종을 동정하였다[24]. 또한, MTB와 NTM 의 검출민감도를 비교 분석하기 위해서 표준결핵균주 MTB $\mathrm{H} 37 \mathrm{Rv}$ 와 M. intracellulare의 균체를 Ogawa 배지로부터 수거 하고 $5 \mathrm{mg} / \mathrm{mL}$ 의 lysozyme을 가하여 $37^{\circ} \mathrm{C}$ 에서 1 시간, $1 \mathrm{mg} / \mathrm{mL}$ 의 proteinase $\mathrm{K}$ 및 $1 \% \mathrm{SDS}$ 를 가하여 $55^{\circ} \mathrm{C}$ 에서 24 시간 반응시 켰고 Cetyl Trimethyl Ammonium Bromide (CTAB)를 첨가하여 $65^{\circ} \mathrm{C}$ 에서 10 분간 반응시키고 페놀 처리 및 에탄올 침전하여 핵 산을 분리하였다.

MolecuTech Real-MTB ID의 MTB와 NTM의 검출민감도를 비교 분석하기 위해서 분리된 DNA를 정량하여 $10 \mathrm{ng}$ 의 DNA 를 $1 \mathrm{fg}$ 까지 연속적으로 10 배씩 희석하여 나온 DNA를 이용하 였으며, MTB-ID (M\&D, Korea)를 이용한 분자진단방법으로 결핵균과 NTM을 구분하였고, REBA Myco-ID (M\&D, Korea) 를 이용하여 제조사가 제공하는 실험설명서에 따라 NTM 균종 을 동정하였다[24].

\section{MolecuTech Real-MTB ID의 수행}

MolecuTech Real-MTB ID (M\&D, Korea)의 수행은 제조사 의 실험설명서에 따라 실험을 수행하였다. 중합효소연쇄반응 액의 조성은 총 $25 \mu \mathrm{L}$ 내에 2X PCR premix (TaKaRa, Shiga, Japan) $12.5 \mu \mathrm{L}$, TB/NTM-IC primer/probe의 혼합물 $7.5 \mu \mathrm{L}$ 와 추출한 검체 DNA $5 \mu \mathrm{L}$ 를 첨가하여 사용하였다. $\mathrm{PCR}$ 반응조 건은 predenaturation을 $94^{\circ} \mathrm{C} 3$ 분간 1 회 수행한 후에 $94^{\circ} \mathrm{C} 20$ 초 denaturation, $60^{\circ} \mathrm{C} 40$ 초 annealing 및 extension 후, 총 40 회의 
A

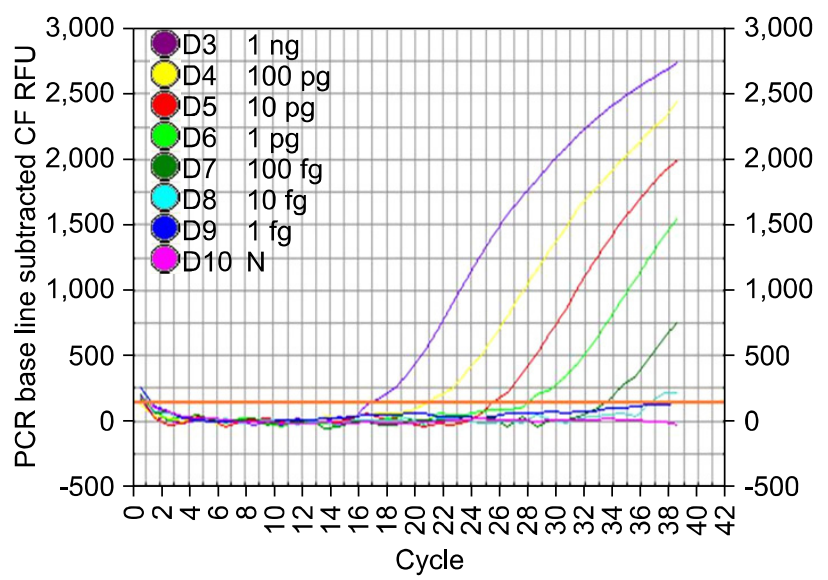

B

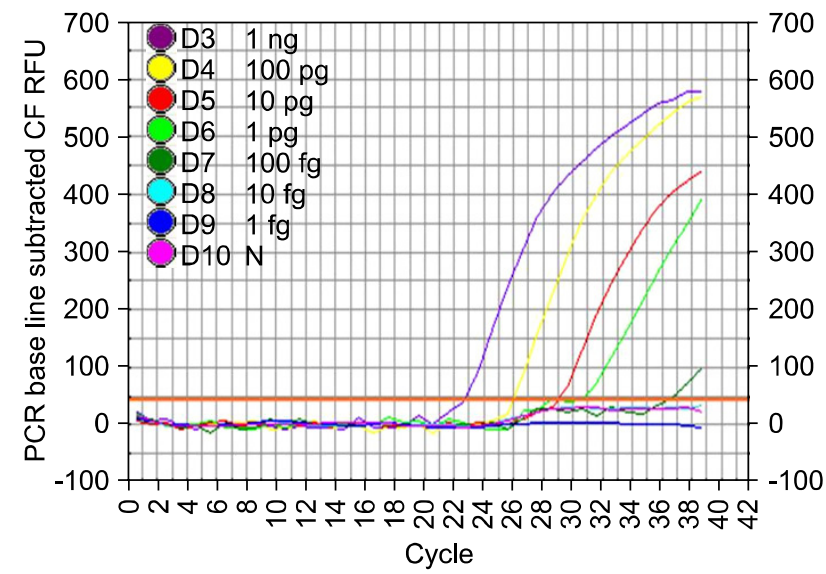

Fig. 1. The sensitivity of the real-time PCR for detecting M. tuberculosis H37Rv (A) and M. intracellulare (B) genomic DNA (A) using FAM dye channel for detecting MTB complex (B) and using ROX dye channel for detecting NTM. Real-time PCR with 1 ng (D3), 100 pg (D4), $10 \mathrm{pg}$ (D5), 1 pg (D6), $100 \mathrm{fg}$ (D7), $10 \mathrm{fg}$ (D8), $1 \mathrm{fg}$ (D9).

반응을 ABI Prism 7500 (Applied Biosystems, Foster City, CA, USA)을 사용하였다. MolecuTech Real-MTB ID는 MTB를 검 출하는 MTB 프로브(FAM)와 mycobacteria 속을 검출하는 Myc 프로브(ROX), 그리고 internal control (IC) 프로브(Cy5)를 포함 하고 있으며, 측정된 threshold cycle $(\mathrm{Ct})$ 값을 분석하여 36 이 하를 양성, 36 을 초과하는 값에 대하여 음성으로 판정하였다. 또한, MTB 프로브가 단독으로 검출되거나 Myc 프로브와 동시 에 검출이 되는 경우에는 $\mathrm{MTB}$ 로 판정하고 $\mathrm{Myc}$ 프로브 단독 으로 검출되는 경우에는 NTM으로 판정하며, IC 프로브를 포 함한 모든 프로브의 시그날이 검출되지 않는 경우에 검사 실패 로 판정한다. MTB 프로브와 Myc 프로브가 동시에 검출되는 경우 중 $\mathrm{Myc}$ 프로브의 $\mathrm{Ct}$ 값이 $\mathrm{MTB}$ 프로브의 $\mathrm{Ct}$ 값보다 낮은 경우에는 MTB와 NTM 모두 존재하는 것으로 판정하였다.

\section{결 과}

\section{MolecuTech Real-MTB ID를 이용한 MTB/NTM의 민감도 분석}

MolecuTech Real-MTB ID의 MTB/NTM의 검출민감도를 비 교 분석하기 위해 M. tuberculosis H37Rv와 M. intracellulare의 $\mathrm{DNA}$ 를 각각 연속적으로 10 배씩 희석한 후 MolecuTech Real$\mathrm{MTB} I D$ 를 수행하였다. 그 결과 MTB에서는 $10 \mathrm{fg}$ 이상의 DNA에서 양성의 결과를 확인할 수 있었고(Fig. 1A), M. intracellulare은 $100 \mathrm{fg}$ 이상의 DNA에서 양성의 결과를 확인할 수 있었다(Fig. 1B). 따라서 MolecuTech Real-MTB ID는 MTB 검 출 민감도가 NTM 검출 민감도보다 10 배 정도 높게 나타나는 것을 확인하였다.
Table 1. Smear and MTB/NTM differentiation results of sputum specimens used in this study

\begin{tabular}{cccc}
\hline \multirow{2}{*}{ AFB smear } & \multicolumn{2}{c}{ Culture confirmation results } & $\begin{array}{c}\text { Total number of } \\
\text { sputum specimens }\end{array}$ \\
\cline { 2 - 4 } & MTB & NTM & 8 \\
\hline Trace & 3 & 5 & 46 \\
+1 & 22 & 24 & 44 \\
+2 & 12 & 32 & 21 \\
+3 & 6 & 15 & 36 \\
+4 & 13 & 20 & 155 \\
\hline Total & 59 & 96 & \\
\hline
\end{tabular}

Abbreviations: AFB, acid-fast bacilli; MTB, M. tuberculosis; NTM, nontuberculous mycobacteria.

\section{2. 임상검체에서 MolecuTech Real-MTB ID를 이용한 MTB/ $\mathrm{NTM}$ 의 검출}

MolecuTech Real-MTB ID의 임상적 유용성 평가를 위해서 도말, 항산균 배양 등의 검사를 통해 최종 동정결과가 $\mathrm{MTB}$ 인 59 개의 객담검체와 NTM인 96개의 객담 검체(Table 1)에 대하 여 real-time PCR을 시행한 결과 59개의 객담 검체 중 58개가 MolecuTech Real-MTB ID에서 MTB 양성 결과를 보였으며 (98.3\%), MTB 음성을 보인 한 검체는 항상균 도말에서 trace을 보인 검체였다. 한편 96 개의 NTM 객담 검체 중 94 개가 MolecuTech Real-MTB ID에서 NTM 양성결과를 보였고 $(97.9 \%)$ 음성의 결과를 나타낸 두 검체는 도말에서 각각 $1+$, 2+였었다. 이러한 결과는 MolecuTech Real-MTB ID의 민감도 가 NTM보다 MTB에서 더 높았던 결과와 일치하는 결과이다 (Table 2).

또한 양성으로 판독한 결과를 기준으로, 염색 결과에 따라 $\mathrm{Ct}$ 값을 비교한 결과 trace에서 $\mathrm{MTB}$ 의 $\mathrm{Ct}$ 값은 31.8 에서 35.06으 
로 나왔으며 NTM의 경우 Myc probe의 Ct값이 28.1에서 35.2 로 나타났으며, $1+$ 에서는 $\mathrm{MTB}$ 의 $\mathrm{Ct}$ 값은 28.8에서 35.3으로 $\mathrm{NTM}$ 의 경우 Myc probe의 Ct값이 26.6에서 35.7로 나타났으 며, 2+에서는 $\mathrm{MTB}$ 의 $\mathrm{Ct}$ 값은 25.8에서 35.5로 NTM의 경우 $\mathrm{Myc}$ probe의 Ct값이 21.7에서 35.6으로 나왔으며, 3+에서는 $\mathrm{MTB}$ 의 $\mathrm{Ct}$ 값은 23.8 에서 30.4로 NTM의 경우 $\mathrm{Myc}$ probe의 $\mathrm{Ct}$ 값이 27.6에서 25.02로 나왔으며, $4+$ 에서는 MTB의 Ct값은 20.4에서 28.8로 NTM의 경우 Myc probe의 Ct값은 23.5에서 34.9로 나온 것을 확인할 수 있었다(Table 2).

\section{3. 임상검체에서 MTB/NTM이 섞여있는 경우의 MolecuTech Real-MTB ID의 결과}

REBA Myco-ID검사를 통해 MTB와 NTM이 함께 검출된 임
상검체를 대상으로 MolecuTech Real-MTB ID의 결과를 비교해 보았다. 그 결과 도말 결과에 따라 $1+$ 에서 MTB와 M. abscessus 검체에서 $\mathrm{MTB}$ 의 $\mathrm{Ct}$ 값이 32.3으로, $\mathrm{Myc}$ probe의 $\mathrm{Ct}$ 값이 31.8로, $\mathrm{MTB}$ 와 M. avium이 나왔던 검체에서는 MTB의 $\mathrm{Ct}$ 값이 33.5으 로, $\mathrm{Myc}$ probe의 $\mathrm{Ct}$ 값이 27.6로 나왔으며, $\mathrm{MTB}$ 와 M. avium로 나왔던 검체에서는 $\mathrm{MTB}$ 의 $\mathrm{Ct}$ 값이 35.3 으로, $\mathrm{Myc}$ probe의 $\mathrm{Ct}$ 값 이 33.8로 나왔으며 도말결과 2+에서 MTB와 M. abscessus로 나온 검체에서 $\mathrm{MTB}$ 의 $\mathrm{Ct}$ 값이 35.5으로, $\mathrm{Myc}$ probe의 $\mathrm{Ct}$ 값이 32.9로 $\mathrm{MTB}$ 의 $\mathrm{Ct}$ 값보다는 $\mathrm{Myc}$ probe의 $\mathrm{Ct}$ 값이 더 낮게 나온 것을 확인 할 수 있었다(Table 3). 또한, 본 연구의 결과에서는 보여주지 않았지만 $\mathrm{MTB}$ 와 NTM의 DNA를 각각 $1: 9,2: 8$, $3: 7,4: 6,5: 5,6: 4,7: 3,8: 2,9: 1$ 의 비율로 일정하게 섞은 후 MolecuTech Real-MTB ID를 실시하여 섞여있는 경우

Table 2. Comparison of MolecuTech Real-MTB ID using sputum specimens

\begin{tabular}{|c|c|c|c|c|c|c|}
\hline \multirow{2}{*}{ AFB smear } & \multicolumn{5}{|c|}{ MolecuTech Real-MTB ID } & \multirow{2}{*}{ Total } \\
\hline & MTB (*) & $\mathrm{Ct}$ & NTM & $\mathrm{Ct}$ & ND & \\
\hline Trace & 2 & $31.8-35.06$ & 5 & $28.1-35.2$ & 1 & 8 \\
\hline $1+$ & $22(1)$ & $28.8-35.3$ & 23 & $26.6-35.7$ & 1 & 46 \\
\hline $2+$ & $12(1)$ & $25.8-35.5$ & 31 & $21.7-35.6$ & 1 & 44 \\
\hline $3+$ & $6(1)$ & $23.8-30.4$ & 15 & $27.6-35.02$ & & 21 \\
\hline $4+$ & 16 & $20.4-28.8$ & 20 & $23.5-34.9$ & & 36 \\
\hline Total & $58(98.3 \%)$ & & $94(97.9 \%)$ & & $3(1.9 \%)$ & 155 \\
\hline
\end{tabular}

(*): number of MTB/NTM mixed case.

Abbreviations: $\mathrm{Ct}$, threshold cycle; ND, not determined.

Table 3. Confirmation of mixed presence of MTB/NTM in sputum by using REBA Myco-ID samples tested in this experiment were the ones determined to contain MTB and NTM by MolecuTech Real-MTB ID

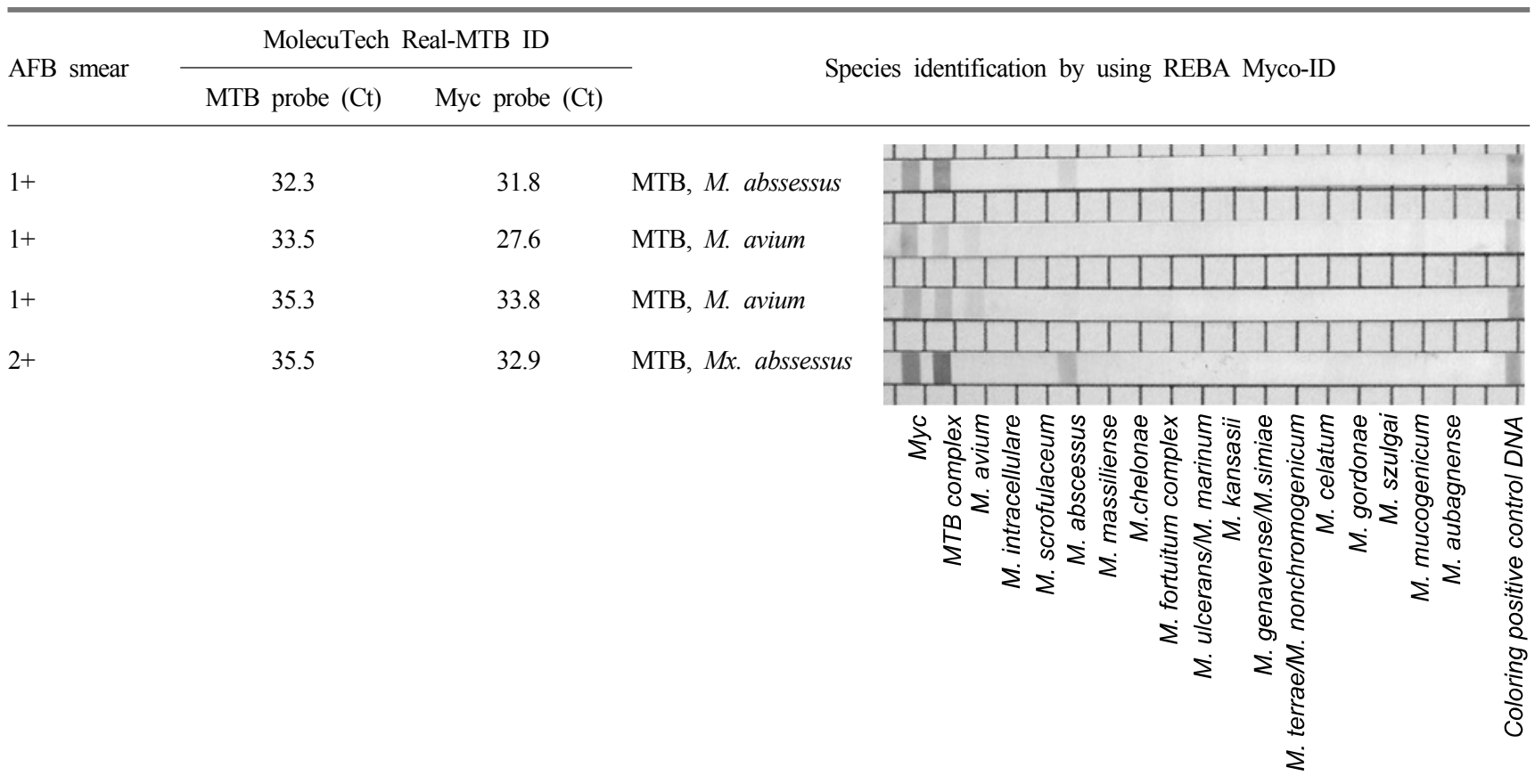

Abbreviation: $\mathrm{Ct}$, threshold cycle. 
어느 정도까지 MTB를 검출할 수 있는지는 확인해보았다. 그 결과 MTB와 NTM DNA가 1 : 9의 비율로 섞여있을 때도 MTB 를 정확하게 검출할 수 있었다. 이와 같이 환자의 검체 내에 MTB와 NTM이 섞여있는 경우에도 MolecuTech Real-MTB ID 는 MTB를 정확하게 검출할 수 있었다.

\section{고 찰}

국내의 경우 결핵의 유병률이 높고 NTM 질환의 빈도가 낮 아 항산균 도말양성일 경우 대부분 결핵균으로 간주하고 항결 핵제 치료를 시행하는 것이 일반적이었다. 그러나 최근 국내에 서도 NTM의 분리율 및 NTM 질환이 증가하고 있고 특히, $\mathrm{NTM}$ 은 면역 기능 저하자에서 질병을 일으킬 수 있고 진단이 쉽지 않으며, 균종에 따른 약제 내성이 다르기 때문에 높아 일 반적인 항결핵제 치료법으로 치료가 어렵고 재발률도 높다[6]. 따라서 임상현장에서 MTB와 NTM을 구별할 수 있는 진단법 의 필요성이 커지고 있다. 이러한 임상적 필요성에 따라 MTB 와 NTM을 구별할 수 있는 다양한 키트들이 개발되어 상용화 되고 있다. 따라서 본 연구에서 직접검체를 대상으로 하여 최 근에 개발된 MolecuTech Real-MTB ID라는 real-time PCR 키 트의 임상적 유용성을 평가해보았다.

삼성서울병원에서 $\mathrm{AFB}$ smear와 배양검사 등이 끝난 155 검 체를 제공받았다. 총 155 검체 중 NTM이 분리된 검체는 59 검 체(38\%)로 이는 국내 NTM 분리율이 $30 \%$ 정도라는 최근의 보 고와 유사한 비율이다. 제공된 검체로 MolecuTech Real-MTB $\mathrm{ID}$ 를 수행하고 이를 검증하기 위해서 동일한 검체의 액체배양 액을 대상으로 하여 MTB과 NTM을 구분하는 PCR 키트인 MTB-ID (M\&D, Korea)를 수행하고 NTM으로 판정된 검체를 대상으로 하여 NTM 균종 동정이 가능한 REBA Myco-ID (M\&D, Korea)를 수행하여 그 결과를 비교하였다.

본 실험의 결과에서 보면 항산 염색상 trace에서의 해당 검체 의 수가 적어 정확한 평가가 어려우나 그 이상에서의 결과를 보면 59개 결핵균 검체 중 58개로 도말양성검체를 대상으로 한 real time PCR에서 98.3\%의 결핵균 양성 결과를 보여 높은 민 감도를 확인할 수 있었다(Table 2). 이러한 결과는 기존에 상품 화되어 나와 있는 E-MTD 키트를 대상으로 한 국내의 연구결 과와 비교해 보면 도말양성 직접검체를 대상으로 한 E-MTD 키트의 민감도는 $93.7 \%$ 였으며[10,11], Amplicor 검사키트를 이 용한 민감도는 97.4\%[2], 또한 국내제품의 AdvanSure TB/ NTM real-time PCR kit를 이용한 민감도 $100 \%[10]$ 와 비교해 볼 때 유사한 결과를 나타내었으며, Broccolo 등[12]의 94\%, Bruijnesteijn Van Coppenraet 등[13] 66.7\%의 결과와 비교해 볼 때 뒤지지 않는 결과라고 판단되었다. E-MTD나 Amplicor 키 트는 MTB만을 검출하지만 본 키트는 MTB와 동시에 NTM의 검출이 가능하다는 장점을 가지고 있다. 또한, 국내에서 NTM
검출에 대한 보고가 많지 않고 평가에 사용된 검체의 수가 적 기는 하나 기존 AdvanSure TB/NTM real-time PCR kit를 이용 한 NTM 배양 양성 검체에서의 민감도는 $55.6 \%$ 라는 보고가 있 다[10]. 이에 비해 본 연구의 결과를 확인해보면 96개의 검체 중 94 개가 NTM으로 판정되어 $97.9 \%$ 의 우수한 검출 능력이 나 타냈으며, 이는 MolecuTech Real-MTB ID 키트가 임상 진료에 유용하게 쓰일 수 있음을 나타내는 것이라고 판단된다. 하지만 조기진단과 치료를 위하여 PCR검사를 시행하는 경우에는 항 산균 염색 음성인 검체에서의 민감도 역시 중요하게 생각된다. 따라서 추후에 항산균 염색 음성인 검체를 대상으로 한 평가가 더 필요할 것으로 보여진다.

한편 검체에 $\mathrm{MTB}$ 와 NTM이 섞여 있는 경우, 배양검사에서 는 천천히 자라는 MTB의 특성상 NTM이 먼저 배양되어 NTM 으로 잘못 판정될 수 있으나 객담과 같은 직접 검체에 MolecuTech Real-MTB ID, REBA Myco-ID 등과 같이 분자생물학적 검사법을 수행을 할 경우에는 이와 같은 문제점들을 해결할 수 있다. 실제로 본 연구에서도 4개의 검체에서 MTB와 NTM이 섞여있는 경우가 있었고 그 중 두 검체에서 성장속도가 빠른 $\mathrm{NTM}$ 인 M. abscessus와 MTB가 섞여있는 경우였고 나머지 두 검체는 성장속도가 느린 NTM인 M. avium이 MTB와 섞여있는 경우였다(Table 3). 이와 같이 객담과 같은 직접 검체에 MTB나 $\mathrm{NTM}$ 이 단독으로 존재하는 경우뿐만 아니라 MTB와 NTM이 섞여있는 경우, 특히 M. abscessus와 같이 빨리 자라는 NTM이 섞여있는 경우에 MolecuTech Real-MTB ID와 같은 분자진단 키트들은 위음성의 오류를 어느 정도 방지할 수 있음을 보여주 고 있다. 또한, 본 연구의 결과에는 보여주지 않았지만 MTB와 $\mathrm{NTM}$ 의 DNA를 각각 다양한 비율로 섞은 후 MolecuTech Real-MTB ID를 실시하였을 때 MTB와 NTM DNA가 1 : 9의 비율로 섞여있을 때도 MTB를 정확하게 검출할 수 있었다.

이상의 결과로 real-time PCR을 이용한 키트인 MolecuTech Real-MTB ID는 우수한 민감도와 특이도로 결핵환자의 호흡기 검체를 대상으로 한 MTB 및 NTM의 진단에 신속하고 유용하 게 사용될 수 있을 것으로 판단된다. 그러나 MolecuTech Real-MTB ID는 추후에 AFB 도말 음성 검체를 포함한 다양한 임상검체와 다양한 임상현장에서의 유용성 평가가 더 필요할 것으로 보인다.

\section{참 고 문 헌}

1. World Health Organization. Global Tuberculosis Control. Surveillance, Planning, Financing. WHO Report 2004. Geneva: World Health Organization, 2004.

2. Chang HE, Heo SR, Yoo KC, Song SH, Kim SH, Kim HB, et al. Detection of Mycobacterium tuberculosis complex using real-time polymerase chain reaction. Korean J Lab Med 2008;28:103-8.

3. Wright PW, Wallace RJ Jr, Wright NW, Brown BA, Griffith DE. Sensitivity of fluorochrome microscopy for detection of Mycobac- 
terium tuberculosis versus nontuberculous mycobacteria. J Clin Microbiol 1998;36:1046-9.

4. Management of opportunist mycobacterial infections: Joint Tuberculosis Committee Guidelines 1999. Subcommittee of the Joint Tuberculosis Committee of the British Thoracic Society. Thorax 2000;55:210-8.

5. Koh WJ, Kwon OJ, Yu CM, Jeon KM, Suh GY, Chung MP, et al. Recovery rate of non-tuberculous mycobacteria from acid-fast bacilli smear-positive sputum specimens. Tuberc Respir Dis 2003; 54:22-32.

6. Koh WJ, Kwon OJ, Lee KS. Diagnosis and treatment of nontuberculous mycobacterial pulmonary diseases: a Korean perspective. J Korean Med Sci 2005;20:913-25.

7. Yeam YS, Jeong OY, Jang SJ, Moon DS, Park YJ. Comparison of culture, Acid-Fast stain and polymerase chain reaction assay for detection of mycobacterium tuberculosis. Korean J Clin Pathol 1995; 15:594-603.

8. Yang HY, Lee HJ, Park SY, Lee KK, Suh JT. Comparison of in-house polymerase chain reaction assay with conventional techniques for the detection of Mycobacterium tuberculosis. Korean $\mathbf{J}$ Lab Med 2006;26:174-8.

9. Chakravorty S and Tyagi JS. Novel multipurpose methodology for detection of Mycobacteria in pulmonary and extrapulmonary specimens by smear microscopy, culture, and PCR. J Clin Microbiol 2005;43:2697-702

10. Kim YJ, Park MY, Kim SY, Cho SA, Hwang SH, Kim HH, et al. Evaluation of the performances of AdvanSure TB/NTM real time PCR kit for detection of mycobacteria in respiratory specimens. Korean J Lab Med 2008;28:34-8.

11. Jung CL, Kim MK, Seo DC, Lee MA. Clinical usefulness of real-time PCR and amplicor MTB PCR assays for diagnosis of tuberculosis. Korean J Clin Microbiol 2008;11:29-33.

12. Broccolo F, Scarpellini P, Locatelli G, Zingale A, Brambilla AM, Cichero $\mathrm{P}$, et al. Rapid diagnosis of mycobacterial infections and quantitation of Mycobacterium tuberculosis load by two real-time calibrated PCR assays. J Clin Microbiol 2003;41:4565-72.

13. Bruijnesteijn Van Coppenraet ES, Lindeboom JA, Prins JM, Peeters MF, Claas EC, Kuijper EJ. Real-time PCR assay using fine-needle aspirates and tissue biopsy specimens for rapid diagnosis of mycobacterial lymphadenitis in children. J Clin Microbiol 2004;42:2644-50.

14. Mäkinen J, Marjamäki M, Marttila H, Soini H. Evaluation of a novel strip test, GenoType Mycobacterium CM/AS, for species identification of mycobacterial cultures. Clin Microbiol Infect
2006;12:481-3.

15. Padilla E, González V, Manterola JM, Pérez A, Quesada MD, Gordillo $\mathrm{S}$, et al. Comparative evaluation of the new version of the INNO-LiPA Mycobacteria and genotype Mycobacterium assays for identification of Mycobacterium species from MB/BacT liquid cultures artificially inoculated with Mycobacterial strains. J Clin Microbiol 2004;42:3083-8.

16. Sanguinetti M, Posteraro B, Ardito F, Zanetti S, Cingolani A, Sechi $\mathrm{L}$, et al. Routine use of PCR-reverse cross-blot hybridization assay for rapid identification of Mycobacterium species growing in liquid media. J Clin Microbiol 1998;36:1530-3.

17. Park H, Jang H, Song E, Chang CL, Lee M, Jeong S, et al. Detection and genotyping of Mycobacterium species from clinical isolates and specimens by oligonucleotide array. J Clin Microbiol 2005;43:1782-8.

18. Park CM, Heo SR, Park KU, Song J, Lee JH, Lee CT, et al. Isolation of nontuberculous mycobacteria using polymerase chain reaction-restriction fragment length polymorphism. Korean J Lab Med 2006;26:161-7.

19. Lee CK, Kim CH, Ma KR, Kim YK, Lee KN, Cheong HJ, et al. Comparison of in-house polymerase chain reaction and Amplicor MTB for diagnosis of tuberculosis in the respiratory specimens. J Korean Soc Chemother 1998;16:97-103.

20. Kim SY, Park YJ, Kang SJ, Kim BK, Kang CS. Comparison of the BDProbeTec ET system with the roche COBAS AMPLICOR System for detection of Mycobacterium tuberculosis complex in the respiratory and pleural fluid specimens. Diagn Microbiol Infect Dis 2004;49:13-8

21. Ho TB, Robertson BD, Taylor GM, Shaw RJ, Young DB. Comparison of Mycobacterium tuberculosis genomes reveals frequent deletions in a $20 \mathrm{~kb}$ variable region in clinical isolates. Yeast 2000; 17:272-82.

22. Talarico S, Durmaz R, Yang Z. Insertion- and deletion-associated genetic diversity of Mycobacterium tuberculosis phospholipase C-encoding genes among 106 clinical isolates from Turkey. J Clin Microbiol 2005;43:533-8.

23. Gordon SV, Brosch R, Billault A, Garnier T, Eiglmeier K, Cole $\mathrm{ST}$. Identification of variable regions in the genomes of tubercle bacilli using bacterial artificial chromosome arrays. Mol Microbiol 1999;32:643-55

24. Lee H, Park HJ, Cho SN, Bai GH, Kim SJ. Species identification of mycobacteria by PCR-restriction fragment length polymorphism of the $r p o B$ gene. J Clin Microbiol 2000;38:2966-71 
$=$ 국문초록=

\section{도말 양성 임상검체에서 MolecuTech Real MTB-ID을 이용한 결핵균과 비결핵균의 검출평가}

${ }^{1}$ 엠앤디(주), ${ }^{2}$ 연세대학교 보건과학대학 임상병리학과, ${ }^{3}$ 영동제약, ${ }^{4}$ 성균관대학교 의과대학 삼성서울병원 호흡기내과 왕혜영 ${ }^{1}$, 진현우 ${ }^{2}$, 방혜은 ${ }^{2}$, 최연임 $^{2}$, 박은미 $^{3}$, 고원중 ${ }^{4}$, 이혜영 ${ }^{2}$

배경: 실시간 중합효소연쇄반응은 유전자의 증폭산물에 결합된 형광물질로부터 방출되는 형광량을 실시간으로 측정하 여 분석하는 방법으로 중합효소연쇄반응 이후 전기영동, 교잡반응과 같은 추가적인 과정없이 분석이 가능하므로 기존 중합효소연쇄반응보다 오염가능성과 위음성의 가능성이 개선되고 검사 소요시간도 단축되는 장점이 있다. 본 연구에서, 국내에서 개발된 real time PCR 제품을 사용하여 임상검체에서 결핵균과 비결핵균을 검출하는 방법을 평가하고자 하였 다.

방법: 민감도 평가는 삼성서울병원에서 의뢰된 155 의 검체(도말, 항산균 배양 등의 검사를 통해 최종 동정결과가 항산균 염색 양성 59 결핵검체와 96 NTM 검체를 대상으로 실시하였다. 검사는 MolecuTech Real MTB-ID ${ }^{\circledR}$ (M\&D, 한국)으로 실시하였으며, 결핵균은 IS6110-RD, 마이코박테리아는 $r p o B$ 유전자를 각각 증폭시켜 검출하였다.

결과: 결핵균과 NTM의 양성률은 결핵균 검체에서 $98.3 \%$ (58/59), NTM 검체에서 $97.9 \%$ (94/96)로 각각 나타났으며 REBA $\mathrm{Myco-ID}{ }^{\circledR}$ 에 의해 결핵균/NTM이 섞여있던 검체의 $\mathrm{MTB} / \mathrm{Myc}$ probe $\mathrm{Ct}$ 값을 비교해 본 결과 32.3-31.8, 35.3-33.8 그리고 35.5-32.9로 Myc probe의 Ct값이 더 높게 나타난 것을 확인할 수 있었다.

결론: MolecuTech Real MTB-ID ${ }^{\mathbb{R}}$ 은 민감도와 특이도가 높게 나타났으며 직접검체에서 결핵균과 NTM을 빠르게 구별하 는 진단에 있어서 유용하게 사용될 수 있을 것으로 판단된다. [대한임상미생물학회지 2011:14:103-109]

교신저자 : 이혜영, 220-710, 강원도 원주시 흥업면 매지리 234

연세대학교 보건과학대학 임상병리학과

Tel: 033-760-2740, Fax: 033-760-2561

E-mail: hyelee@yonsei.ac.kr 